\title{
Effects of Aggregate Extraction on Water Storage in the Pepin Creek Watershed, British Columbia, Canada
}

\author{
Yining Wang1, Julie E. Wilson1, Drew Brayshaw ${ }^{2}$, Les M. Lavkulich ${ }^{*}$ \\ ${ }^{1}$ Master of Land and Water Systems, Faculty of Land and Food Systems, The University of British Columbia, Vancouver, Canada \\ ${ }^{2}$ Statlu Environmental Consulting Ltd., Chilliwack, Canada \\ Email: *lml@mail.ubc.ca
}

How to cite this paper: Wang, Y.N., Wilson, J.E., Brayshaw, D. and Lavkulich, L.M. (2017) Effects of Aggregate Extraction on Water Storage in the Pepin Creek Watershed, British Columbia, Canada. Natural Resources, 8, 461-477.

https://doi.org/10.4236/nr.2017.87030

Received: June 24, 2017

Accepted: July 24, 2017

Published: July 27, 2017

Copyright $\odot 2017$ by authors and Scientific Research Publishing Inc. This work is licensed under the Creative Commons Attribution International License (CC BY 4.0).

http://creativecommons.org/licenses/by/4.0/

\begin{abstract}
Aggregate extraction in the Lower Fraser Valley of British Columbia, Canada, has affected the soil water storage of the Pepin Creek watershed. Although local government has set regulations for aggregate extraction projects to avoid negative environmental impacts, the gradual loss of soil materials and associated changes in vegetative cover has led to an alteration of the water balance within the watershed, which may affect surface or groundwater levels, and aquatic habitats. The study assessed the effects of aggregate extraction on the water storage of the Pepin Creek watershed and estimated that $25 \%$ of the surface area of the Canadian portion of the watershed has been affected by aggregate mining with an estimated loss of water storage of $10 \%$. Evapotranspiration has decreased as a result of the removal of the vegetative cover. Precipitation has remained relatively constant over the study period but the annual discharge measured at Pepin Creek has decreased. Recommendations for enhancing environmental monitoring to better measure and understand ecological functions of the watershed during aggregate extraction are provided.
\end{abstract}

\section{Keywords}

Soil Water Storage, Aggregate Extraction, Water Balance, Watershed Storage

\section{Introduction}

Aggregate materials (e.g., rock, gravel, sand and stone) are important for construction, transportation and urban structure maintenance activities. It has been estimated that each Canadian uses, indirectly, 10 to 16 tonnes of aggregate per year [1]. As the demand for aggregates continues to increase, particularly by the 
construction industry, aggregate mining in the Fraser Valley and Metro Vancouver Regional Districts is also increasing [2]. Thus, there is a concern that the process of mining aggregate can have a potentially significant impact on the surrounding environment [3]. The Fraser Valley Regional District FVRD immediately identifies the major concerns as: noise, dust, blasting and vibration, traffic and road safety, agricultural and public health, sediment erosion, drainage, and impacts on water supplies [2]. Aggregate extraction may disrupt the water balance and impact the hydrological cycle of a watershed. In addition, the watershed may decrease its capacity of assimilating contaminants as a result of the changes of the stream regime, such as flow and temperature [4]. From the perspective of water resources, aggregate extraction may also impact water quality on and nearby extraction sites, such as residential wells, as deleterious substances may enter the watershed through groundwater and surface run off [5]. These in turn, may negatively affect wetlands and on-site lakes, with reduced water levels and increased summer water temperatures, which may be detrimental to cool water fish.

However, aggregates are in high demand in Metro Vancouver, which suggests that aggregate mining will continue within the study area. The goal of this study was to provide an assessment of the effects of aggregate extraction on the calculated water balance within a watershed with a focus on the effects on water storage. The Pepin Creek watershed, which contains several active mine sites for sand and gravel extraction, was selected as the case study to assess the effects of aggregate extraction on water balance dynamics.

The objectives of the study were to assess the effects of aggregate mining on the water balance, notably the water storage of Pepin Creek watershed, to identify potential environmental impacts of aggregate removal, and to suggest mitigation measures to decrease potential negative ecological effects.

\section{Methods}

\section{Study Area}

Pepin Creek watershed, located in the Lower Fraser Valley, was selected as a case study as it has a well-documented history of aggregate extraction (Figure 1). Pepin Creek is located within the Bertrand Creek watershed, south of the City of Abbotsford, British Columbia, Canada and flows into Whatcom County, Washington, USA $\left(49^{\circ} 00^{\prime} 13^{\prime \prime} \mathrm{N}, 122^{\circ} 28^{\prime} 18^{\prime \prime} \mathrm{W}\right)$. The Canadian portion of the Pepin Creek watershed is approximately 16.5 square $\mathrm{km}$ in area, and $7.5 \mathrm{~km}$ in length at its longest point [6].

Aggregate extraction within the district started in the early 1960s, and the scale of extraction has increased relatively rapidly since that time [2]. An example of the area affected by aggregate mining is shown in Figure 2. The surficial deposits are described as Sumas Drift [7]. The dominant materials are mediumtextured aeolian materials overlying several meters of glaciofluvial sands and gravels [8]. The soils are well drained and possess good permeability.

Geographical data, including maps and boundaries of aggregate sites were 


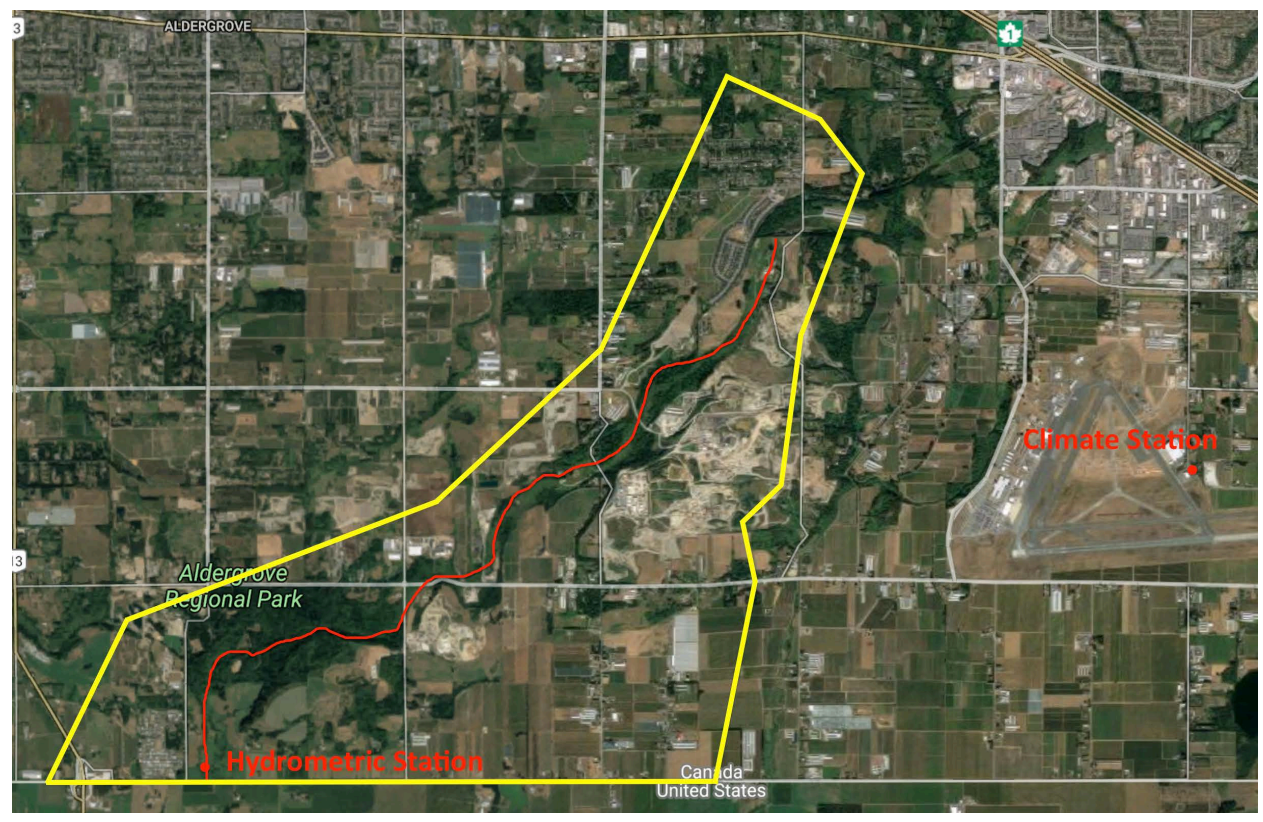

Figure 1. Boundary of Pepin Creek watershed (within Canada) and location of climate and hydrometric stations.

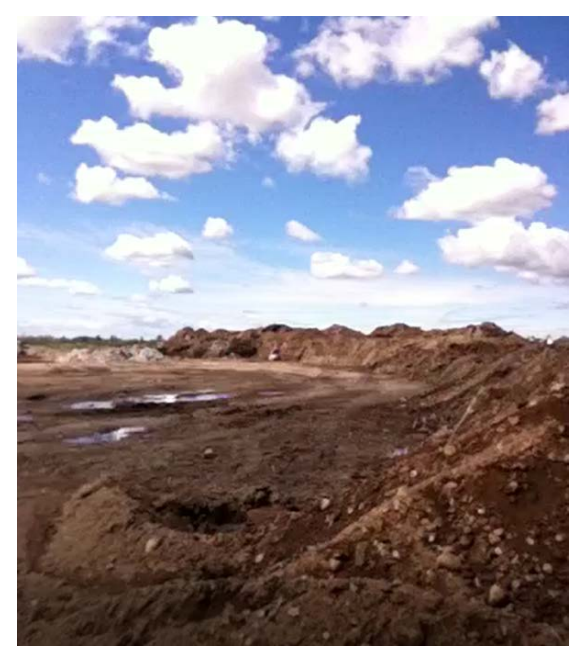

Figure 2. Excavated soil and surficial materials at an aggregate extraction site in Pepin Creek watershed (Image source: L. M. Lavkulich).

obtained for Pepin Creek Watershed from 1984 to 2011, at a 4 - 5 year interval from: Air photos of Abbotsford from 1984 to 2004 [9], 2009 Olympic imagery series [6], and Google Earth historical maps from 2004-2011 [10].

Hydrometric data were obtained from the hydrometric station located at the Canada-USA border [11]: Station Number: 08MH156, Latitude and Longitude: $49^{\circ} 00^{\prime} 13^{\prime \prime} \mathrm{N}, 122^{\circ} 28^{\prime} 18^{\prime \prime} \mathrm{W}$, with gross drainage area of approximately $6 \mathrm{~km}^{2}$ and flow measured between May and October, 1984-2011.

Climate data were obtained from the climate station located at Abbotsford Airport, located about $3 \mathrm{~km}$ east of the Pepin Creek watershed [12]: Climate Station ID: 1100030, WMO ID: 71108, TC ID: YXX, Latitude and Longitude: 
$49^{\circ} 00^{\prime} 31^{\prime \prime} \mathrm{N} 122^{\circ} 21^{\prime} 36^{\prime \prime} \mathrm{W}$, and Elevation: $59 \mathrm{~m}$. The most complete data set that coincides with the majority of active mining within the watershed was for the period of May to October, 1985-2011, and included monthly mean, maximum and minimum rainfall, snowfall and total precipitation.

ArcGIS [13] was used to assess the aggregate extraction sites and their distribution within the study area over time and to the calculation of the volume of aggregate removed [14]-[20]. Depth and area for each aggregate extraction site were also estimated using ArcGIS. To calculate the water holding capacity ( WHC) of the removed aggregate, bulk density and water holding capacity information was obtained from [8]. General linear trend lines in the figures are presented for general visualization and calculated by regression analysis. As there is considerable spread in the limited data presented in the figures, the trend lines are not statistically significant and serve only to provide a general direction of the trend.

Water storage $(S)$ was calculated by Equation (1) [21]:

$$
S=V \times \rho \times W H C / 1000
$$

where:

$S=$ the water storage of material removed $\left(\mathrm{m}^{3}\right)$,

$V=$ the volume of materials removed $\left(\mathrm{m}^{3}\right)$,

$\rho=$ the bulk density of materials removed $\left(\mathrm{kg} / \mathrm{m}^{3}\right)$,

$W H C=$ the water holding capacity of materials removed $(\mathrm{kg} / \mathrm{kg})$, and 1000 mass $(\mathrm{kg})$ of water to volume $\left(\mathrm{m}^{3}\right)$.

The volume of water lost as a result of the removal of the soil material, or storage $(S)$, was estimated from the water balance Equation (2) presented in [21]:

$$
Q=I N P U T+\Delta S-E T
$$

where:

$Q=$ the water discharge monitored for Pepin Creek $\left(\mathrm{m}^{3}\right)$,

$I N P U T=$ the water input into the watershed (precipitation) $\left(\mathrm{m}^{3}\right)$,

$\Delta S=$ the change in water storage within the watershed,

$E T=$ the evapotranspiration from vegetation $\left(\mathrm{m}^{3}\right)$.

Equation (2) assumes there is no surface runoff, nor water entering from adjacent sources.

To calculate actual evaporation, Equation (3) from [22] was used:

$$
E A / E T=C_{2}+\left(1-C_{2}\right)\left[\left(S M-F C+C_{4}\right) / C_{4}\right]
$$

where:

$E A=$ actual evaporation, and

$E T=$ the potential evaporation from a grass surface.

The calculation is based on the assumption that the soil is saturated, or not below field capacity $(F C)$ and is equal to soil moisture $(S M)$ at the beginning of the growing season. $C_{2}$ and $C_{4}$ are soil moisture loss values that change if $S M$ becomes less than $F C$ and are constant at a site. Kristensen and Jensen [22] define $C_{2}$ as the evaporation taking place, regardless of vegetation density and soil 
dryness; $C_{4}$ is the amount of soil water that should be removed from the upper soil layer to reduce the evaporation from bare soil to the equivalent of $C_{2}$. If $S M$ remains above $F C, E A / E T$ equals 1 , or evapotranspiration from bare soil, $E A$, equals the evapotranspiration of the soil with grass, $E T$.

\section{Results}

\subsection{Water Balance}

The study focused on a 26-year time interval, from 1985 to 2011, which had the most complete data available. Data availability was limited by the frequency of hydrometric data collection on Pepin Creek. The discharge measured on Pepin Creek and total precipitation, from May to October for the time period, are plotted in Figure 3. The total precipitation and potential evapotranspiration is shown in Figure 4. The interval linear trend lines plotted in the figures are from regression calculation and presented to serve as general guides. The variability over the relatively short time frame does not lend itself to statistical trend analysis.
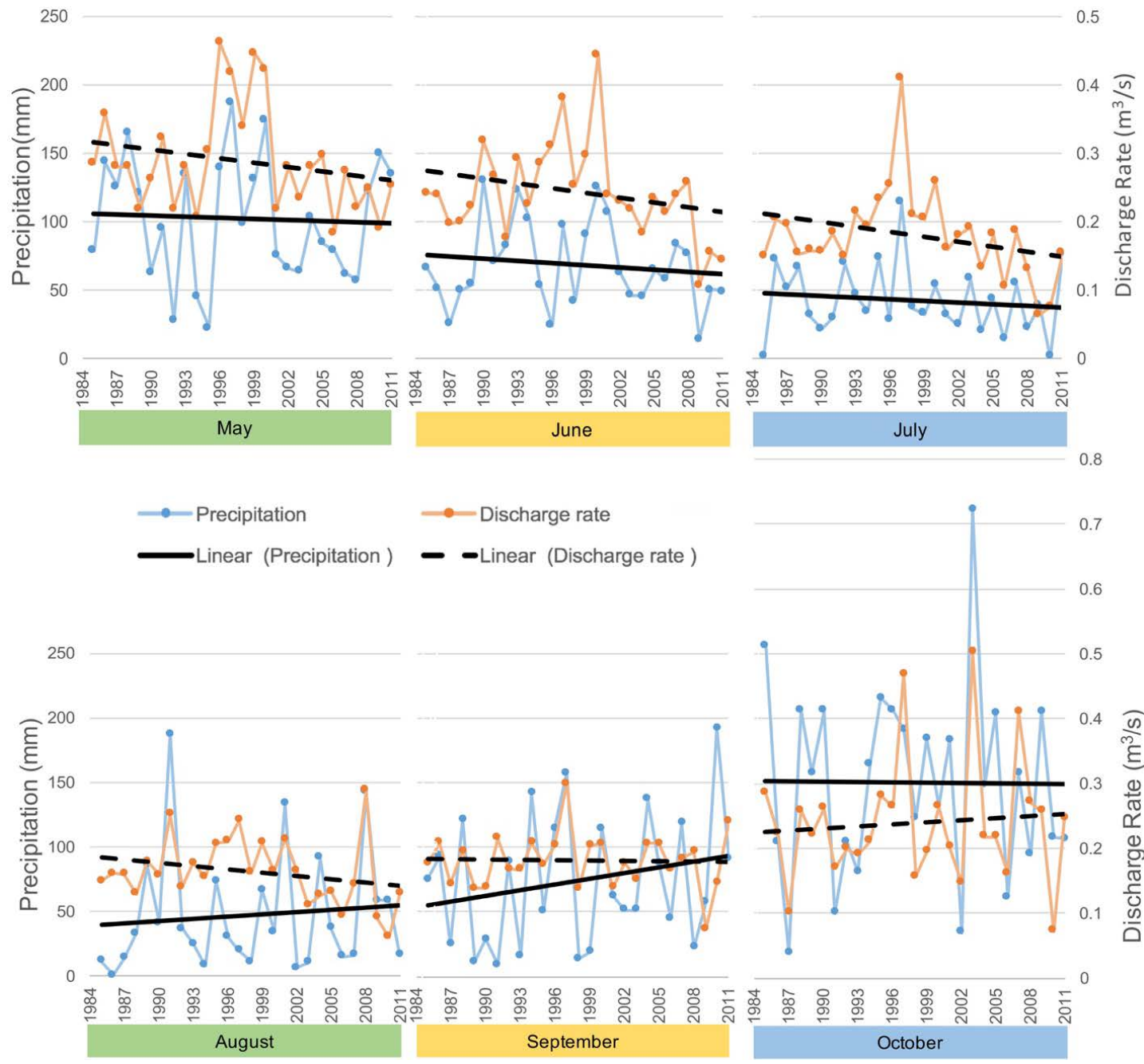

Figure 3. Total precipitation in Pepin Creek watershed and discharge rate of Pepin Creek during the growing season from 1985 to 2011. (Note: Linear trend line shows general direction of trend; not statistically significant). 


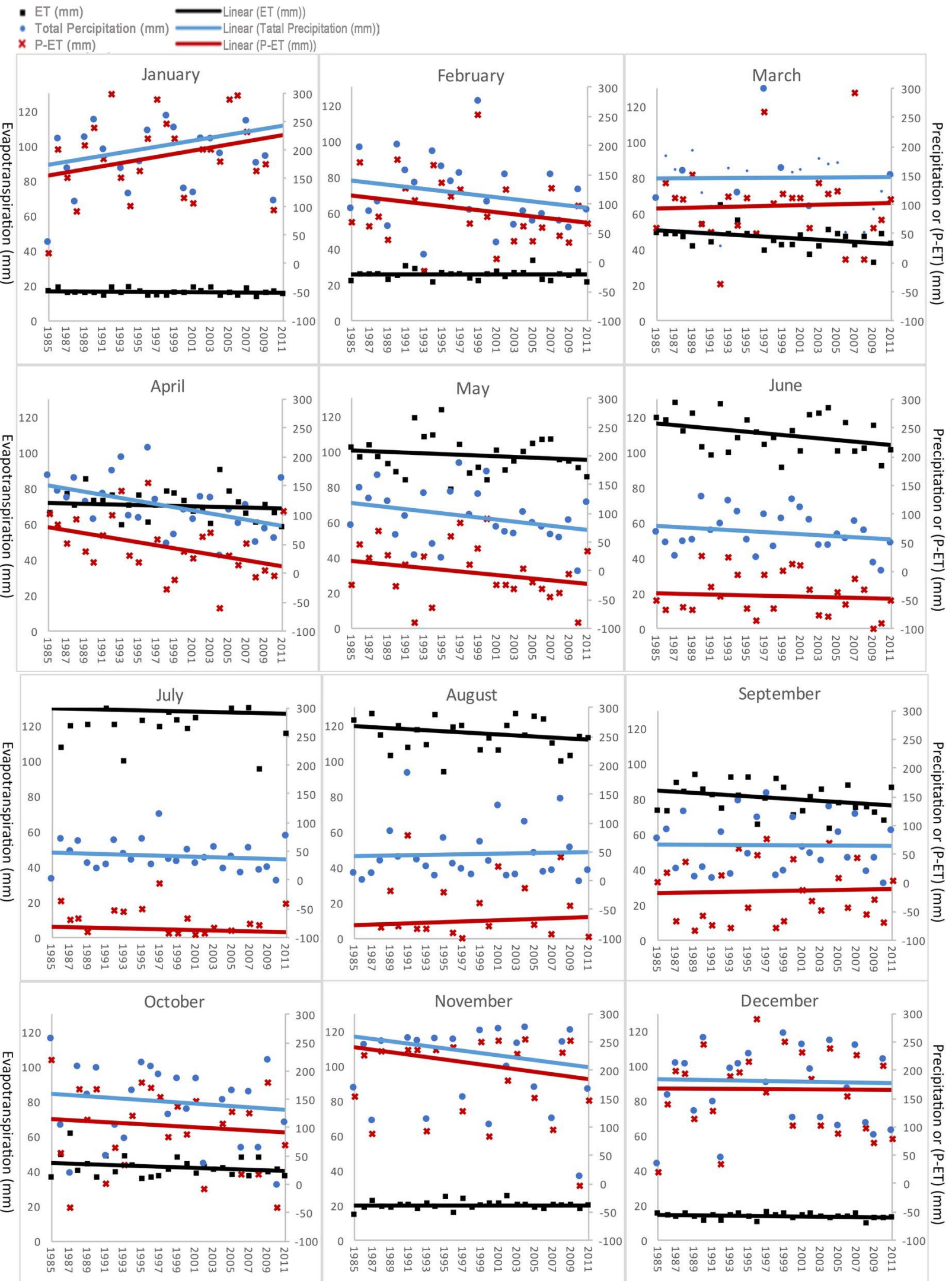

Figure 4. Potential evapotranspiration and total precipitation for the Pepin Creek watershed. (Note: Linear trend line shows general direction of trend; not statistically significant). 
Figure 3 indicates that although there has been a slight decrease in both total precipitation and discharge rate from June until the month of August, after which there is a leveling of the discharge data, over the 26 years. When precipitation begins to increase in September there is an increase in the discharge rate measured on Pepin Creek in the following month of October.

As Figure 3 and Figure 4 illustrate, over the 26 years, there has been little change in precipitation with only a slight increase in January; the discharge trend in August, September and October is not synchronous with the precipitation trend over the time period. The discharge should correspond with the precipitation when soils are saturated in a balanced hydrological cycle. However, in the latter part of the dry season in August and September, the monthly precipitation has increased over the 26 years, while the discharge has decreased. In addition, for May, June and July both precipitation and discharge rates have decreased.

Separating the results for potential evapotranspiration and total precipitation within the watershed by growing season shows that the largest change has been in evapotranspiration in the dry season over the 26-year period (Figure 5).

There are three possible causes of the reduction in the apparent discharge, which are discussed in the following section:

1) A change in climate;

2) The loss of surface vegetation and evapotranspiration due to land clearing for aggregate extraction; and

3) The loss of water storage due to aggregate extraction.

\subsection{Change in Climate}

A comparison of total volume of precipitation and discharge between May and October is shown in Figure 6 and Figure 7.

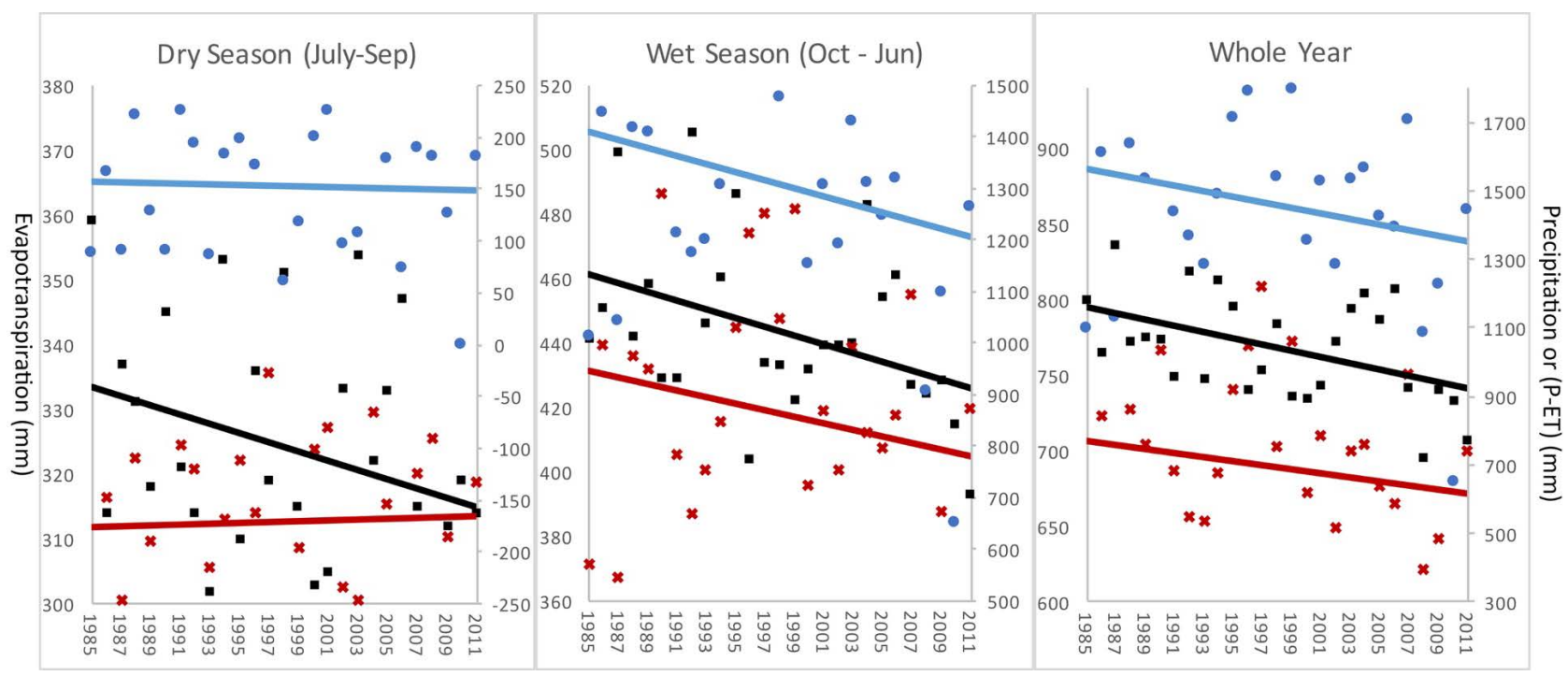

Figure 5. Potential evapotranspiration and total precipitation by season (wet and dry) and the complete year for Pepin Creek from 1985 to 2011. (Note: Linear trend line shows general direction of trend; not statistically significant). 


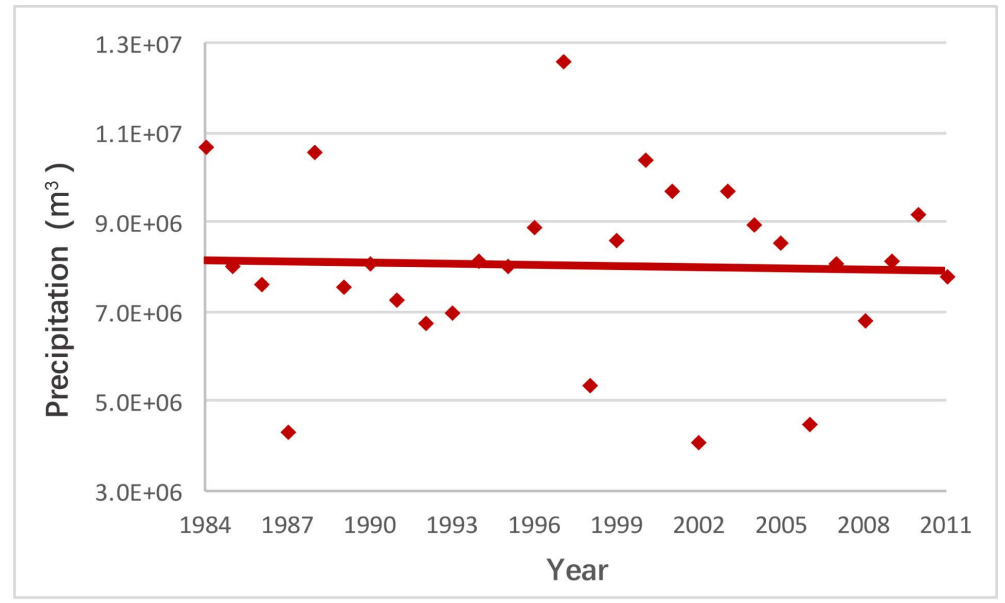

Figure 6. Volume of total annual precipitation in $\mathrm{m}^{3}$ (May-Oct.) calculated for the Pepin Creek watershed. (Note: Linear trend line shows general direction of trend; not statistically significant).

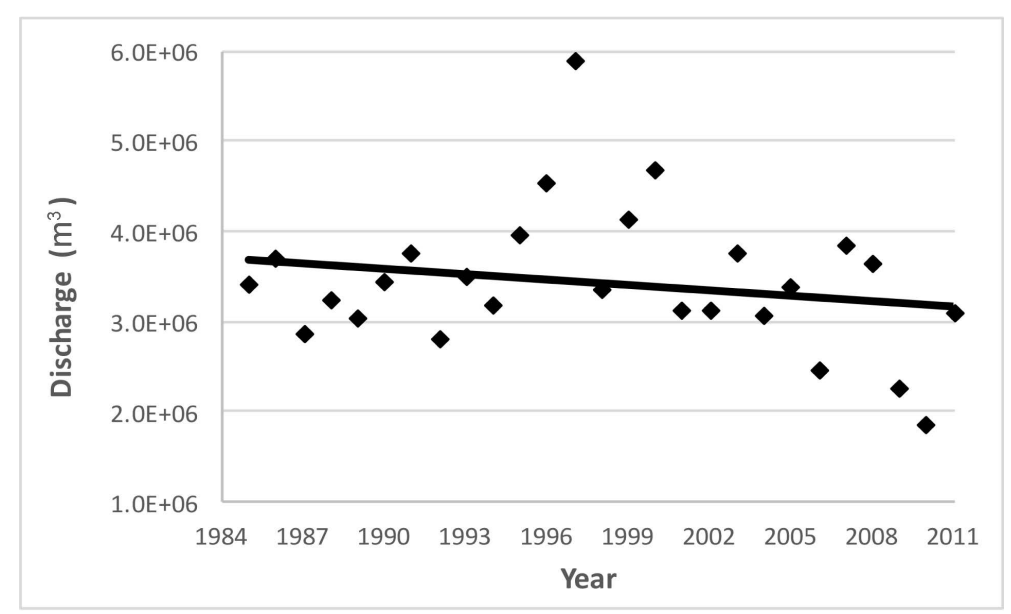

Figure 7. Volume of total annual discharge in $\mathrm{m}^{3}$ (May-Oct.) in Pepin Creek. (Note: Linear trend line shows general direction of trend; not statistically significant).

There is large variation in both precipitation and discharge measured annually. The total precipitation data suggest a slight negative trend but overall remain relatively stable, while the trend of total discharge exhibits a more pronounced negative trend. Since the reduction of the total discharge appears to be of greater magnitude than total precipitation, the reduction of discharge over the 6 months cannot be attributed exclusively to climate.

\subsection{Loss of Vegetation (Bare Soil)}

As a result of aggregate mining, there has been a progressive increase in nonvegetated surface area, and therefore a potential decrease in potential plant $E T$ and total $E T$ in the watershed. This is partially offset by the increase in evaporation from the soil. The overall effect of vegetation removal can be analyzed using Equation (3) from [22]. 
The calculation is based on the assumption that soil is initially saturated and soil moisture $(S M)$ remains at field capacity $(F C) . C_{2}$ and $C_{4}$ are soil moisture loss constants that change if $S M$ becomes less than $F C$. If we assume that $S M$ does not fall below $F C$ then $E A / E T=1$, which means the evapotranspiration of bare soil $(E A)$, equals the evapotranspiration of soil with grass $(E T)$. Therefore, under this assumption, which is conservative, the loss of vegetation should not cause a large change in discharge. In estimating evapotranspiration from land surfaces in British Columbia, Spittle house [23] suggested that:

$$
E T=\alpha E_{e q}
$$

where:

$$
\begin{aligned}
& \alpha=\text { a dimensionless constant, and } \\
& E_{e q}=\text { the equilibrium evaporation rate. }
\end{aligned}
$$

Values for $\alpha$ in the Lower Fraser Valley are 1.26 \pm 0.1 for pasture and $1.27 \pm$ 0.1 for bare soil, which suggests that in the region there is little difference in $E T$ as a result of changes in the soil vegetative cover [23]. However, in the dry season, the actual soil moisture in unirrigated soil could be below field capacity; that is, the $E A$ will be slightly below the $E T$. If this is correct, then the extra water ( $E T-E A$ ) could be retained in the soil and eventually contribute to discharge.

\subsection{Loss of Water Storage}

To ascertain if a vegetative cover is significant we calculated the effects of two hypothetical scenarios. The first was to assume all the area was planted with sweet corn, the dominant cash crop in the region, and the second scenario with grass, which is common practice used in restoration projects. Assigning the land use in Pepin Creek watershed to sweet corn or grass, the calculated water storage $(S)$ was then estimated with Equation (5) [24]:

$$
Q=\text { Precipitation }+\Delta S-E T
$$

If sweet corn is selected as an example vegetative cover, the calculation for evapotranspiration of sweet corn may be obtained by use of Equation (6):

$$
E T_{c}=E T_{0} \times K_{c}
$$

where:

$$
\begin{aligned}
& E T_{c}=\text { evapotranspiration of sweet corn ( } \mathrm{mm} / \text { day), } \\
& E T_{0}=\text { reference evapotranspiration (grass) }(\mathrm{mm}) \text {, and } \\
& K_{c}=\text { single crop coefficient. }
\end{aligned}
$$

$K_{c}$ is an empirical crop coefficient that has been adapted to the Pepin Creek area [21]. The growing stage and corresponding coefficient was obtained from [25] and [26] and is presented in Table 1. The growing season was assumed to be 120 days, followed by 14 days of harvest, and no growth (fallow) for the remainder of the season (50 days), when the land is assumed to be bare and thus equal to the reference evapotranspiration rate $\left(E T_{0}\right)$.

After mapping the active extraction sites in the study area by year, the bare soil area and area covered with vegetation was calculated using ArcGIS [13]. 
Combining the area values with the evapotranspiration data from [26], total evapotranspiration of both sweet corn and grass were calculated and the results are presented in Table 2.

The water storage of Pepin Creek watershed was calculated by Equation (7):

$$
S=Q+E T-\text { Precipitation }
$$

Figure 8 shows that the change in water storage of the study area is decreasing over time. Combining both the climate and hydrological data indicates that the water balance has been affected by the removal of the aggregates from the site, regardless of whether the cover is sweet corn or grass. In the year of 1997, there was extraordinarily high precipitation, which resulted in the unusual low storage value in Figure 8. However, when the 1997 data is exempted, the trend lines for both scenarios still have negative trends.

The data for 1997 necessitates further discussion. As noted in Table 3, that year reported an exceptionally high volume of precipitation (over $50 \%$ higher than the average for the eight years). If one ignores that single year, the overall trend remains slightly negative.

This observation helps to explain the observed trends between precipitation and discharge during August to October. In July, the dry season, the discharge is high and probably influenced by the base flow from the previous winter. As a result of the reduced annual change in water storage, in the remainder of the dry season (August and September), the site did not store as much water, thus the excess contributed to discharge. In conclusion, the major impact has been the

Table 1. Growing stage and single crop coefficient of BC sweet corn (adapted from [25] [26]).

\begin{tabular}{cccc}
\hline \multicolumn{1}{c}{ Stage } & & Days & $\boldsymbol{K}_{\boldsymbol{c}}$ \\
\hline Germination \& Establishment & Initial & 20 & 0.3 \\
Vegetation & Corn Development & 35 & $0.3-1.15$ \\
Tasselling, Silking \& Pollination & Mid-Season & 40 & 1.15 \\
Kernel Development & & 25 & $0.4-1.15$ \\
Maturity & Late Season & 14 & 0.4 \\
Bare Soil & Harvest & 50 & 1 \\
\hline
\end{tabular}

Table 2. Total evapotranspiration of Pepin Creek watershed calculated under grass or sweet corn vegetative cover.

\begin{tabular}{ccccccccc}
\hline Year & 1985 & 1988 & 1994 & 1997 & 1999 & 2002 & 2007 & 2011 \\
\hline 6 month ET $(\mathrm{mm})$ & 616 & 581 & 612 & 563 & 544 & 586 & 559 & 537 \\
Extraction area $\left(\mathrm{m}^{2} \times 10^{6}\right)$ & 1.16 & 1.33 & 2.28 & 2.30 & 2.39 & 2.68 & 3.19 & 3.11 \\
Evaporation of bare soil $\left(\mathrm{m}^{3} \times 10^{6}\right)$ & 0.72 & 0.78 & 1.40 & 1.30 & 1.30 & 1.57 & 1.78 & 1.67 \\
Area with Vegetation $\left(\mathrm{m}^{2} \times 10^{6}\right)$ & 15.2 & 15.0 & 14.1 & 14.0 & 13.9 & 13.7 & 13.2 & 13.2 \\
6 month ET (grass) $\left(\mathrm{m}^{3} \times 10^{6}\right)$ & 9.35 & 8.72 & 8.60 & 7.90 & 7.59 & 8.01 & 7.35 & 7.11 \\
6 month ET (corn) $\left(\mathrm{m}^{3} \times 10^{6}\right)$ & 7.20 & 6.71 & 6.63 & 6.09 & 5.84 & 6.16 & 5.66 & 5.47 \\
Total ET (grass) $\left(\mathrm{m}^{3} \times 10^{6}\right)$ & 10.1 & 9.49 & 10.0 & 9.20 & 8.89 & 9.58 & 9.13 & 8.78 \\
Total ET (corn) $\left(\mathrm{m}^{3} \times 10^{6}\right)$ & 7.92 & 7.49 & 8.02 & 7.38 & 7.14 & 7.73 & 7.44 & 7.14 \\
\hline
\end{tabular}


loss of materials by aggregate mining, resulting in the decreased water storage in the watershed.

\subsection{Quantifying the Change in Annual Water Storage}

A series of maps identifying the areas under aggregate extraction were constructed using ArcGIS, with examples from 1984, 1999 and 2011 shown in Figure 9. The images confirm that the Pepin Creek watershed has experienced a marked increase in the area of extracted aggregates, which is summarized in Table 4.

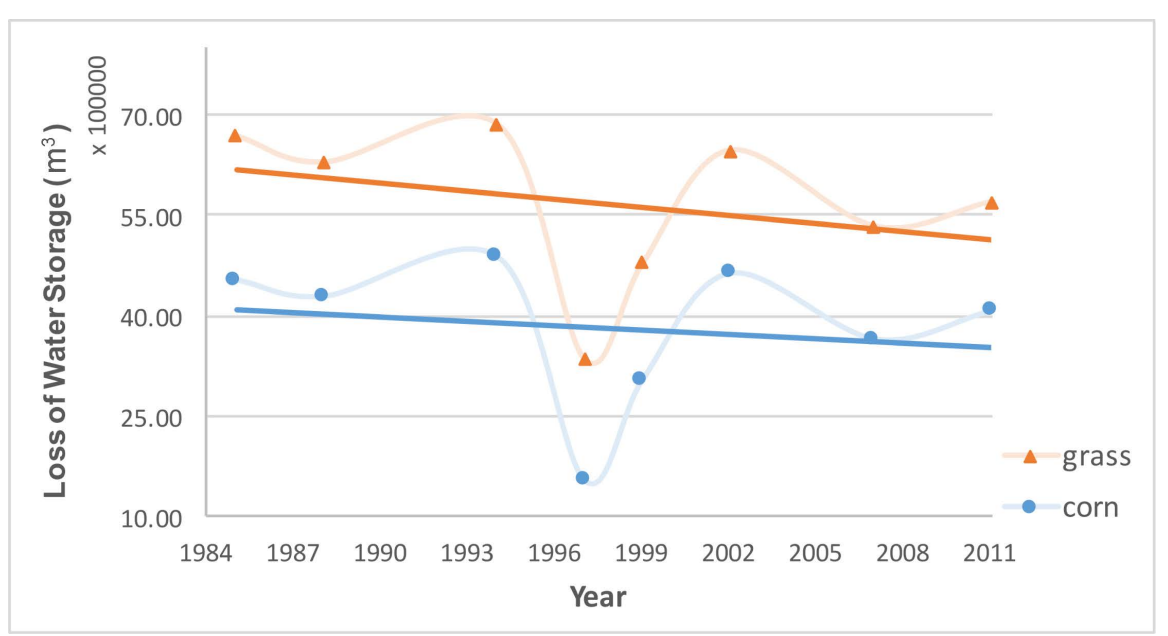

Figure 8. Loss of water storage $(S)$ of Pepin Creek watershed calculated under grass or sweet corn vegetative cover. (Note: Linear trend line shows general direction of trend; not statistically significant).
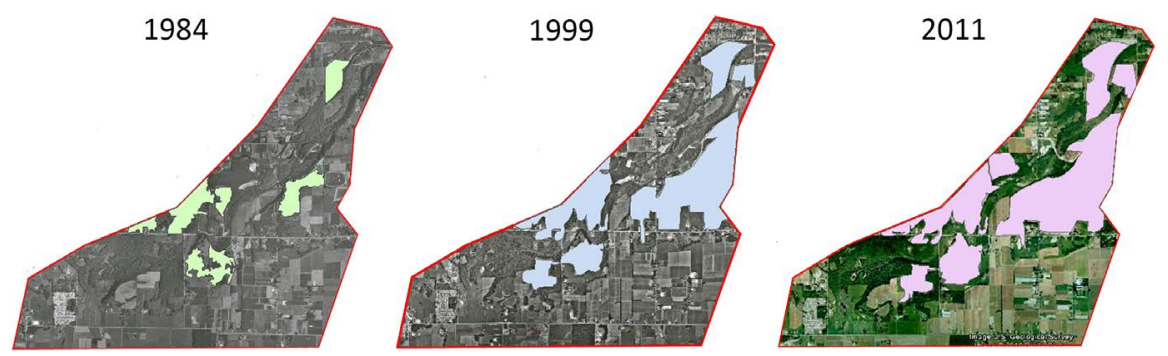

Figure 9. Aggregate extraction area in Pepin Creek watershed in 1984 (green), 1999 (blue) and 2011 (pink).

Table 3. Water storage change of Pepin Creek watershed calculated under grass or sweet corn vegetative cover.

\begin{tabular}{ccccccccc}
\hline & 1985 & 1988 & 1994 & 1997 & 1999 & 2002 & 2007 & 2011 \\
\hline Input (precipitation) $\left(\mathrm{m}^{3} \times 10^{6}\right)$ & 3.40 & 3.22 & 3.17 & 5.88 & 4.11 & 3.12 & 3.81 & 3.09 \\
Q (discharge) $\left(\mathrm{m}^{3}\right)$ & 8010 & 10500 & 8120 & 12500 & 8580 & 4030 & 8050 & 7740 \\
Total ET (grass) $\left(\mathrm{m}^{3} \times 10^{6}\right)$ & 10.1 & 9.49 & 10.0 & 9.20 & 8.89 & 9.58 & 9.13 & 8.78 \\
Total ET (corn) $\left(\mathrm{m}^{3} \times 10^{6}\right)$ & 7.92 & 7.49 & 8.02 & 7.38 & 7.14 & 7.73 & 7.44 & 7.14 \\
$\mathrm{~S}$ (with grass) $\left(\mathrm{m}^{3} \times 10^{6}\right)$ & 6.67 & 6.28 & 6.84 & 3.34 & 4.79 & 6.46 & 5.33 & 5.69 \\
$\mathrm{~S}$ (with corn) $\left(\mathrm{m}^{3} \times 10^{6}\right)$ & 4.52 & 4.28 & 4.86 & 1.52 & 3.04 & 4.62 & 3.64 & 4.06 \\
\hline
\end{tabular}


Figure 9 shows the extent of aggregate extraction areas in the Pepin Creek watershed since 1984. At the beginning of the study period (1984), there were only a few parcels under extraction, with a total area of 116 hectares. In 1999, the area of extracted area had more than doubled to 326 ha, and by 2011, had increased again to 421 ha, encompassing about $25 \%$ of the watershed area north of the international boundary.

The gravel extraction sites were divided into 6 districts. The depth of each pit was obtained from Abbotsford Council Reports for soil removal and the amount of material removed was estimated by extrapolation from the reported duration of construction outlined in these reports [14]-[20]. Bulk density and water holding capacity information of the removed material was derived from [8] to calculate total water stored in Table 4.

Figure 10 presents the actual loss of water storage in the Pepin Creek watershed under the scenario that all vegetation is grass or sweet corn with no irrigation. The positive trends suggest that the aggregate extraction is progressing relatively rapidly. The compensation value of re-establishing a vegetative cover approximately equals the total actual water storage of the watershed and the water storage of material extracted; that is, the value represents the amount of water that could be held.

Interestingly, the loss of water storage under grass cover is relatively unchanged over time (Figure 10), suggesting that change in annual storage over

Table 4. Area under aggregate extraction, the cumulative volume of material removed and the water storage $(S)$ lost due to aggregate extraction in the Pepin Creek watershed (1984-2011).

\begin{tabular}{cccccccccc}
\hline & 1984 & 1988 & 1994 & 1997 & 1999 & 2002 & 2007 & 2011 \\
\hline Total area $(\mathrm{ha})$ & 116 & 139 & 257 & 290 & 326 & 394 & 402 & 413 \\
Total aggregate removed $\left(\mathrm{m}^{3} \times 10^{6}\right)$ & 13.9 & 16.3 & 30.9 & 35.4 & 40.0 & 48.3 & 49.2 & 50.2 \\
Total water stored $\left(\mathrm{m}^{3} \times 10^{6}\right)$ & 0.39 & 0.45 & 0.85 & 0.98 & 1.10 & 1.33 & 1.35 & 1.38 \\
\hline
\end{tabular}

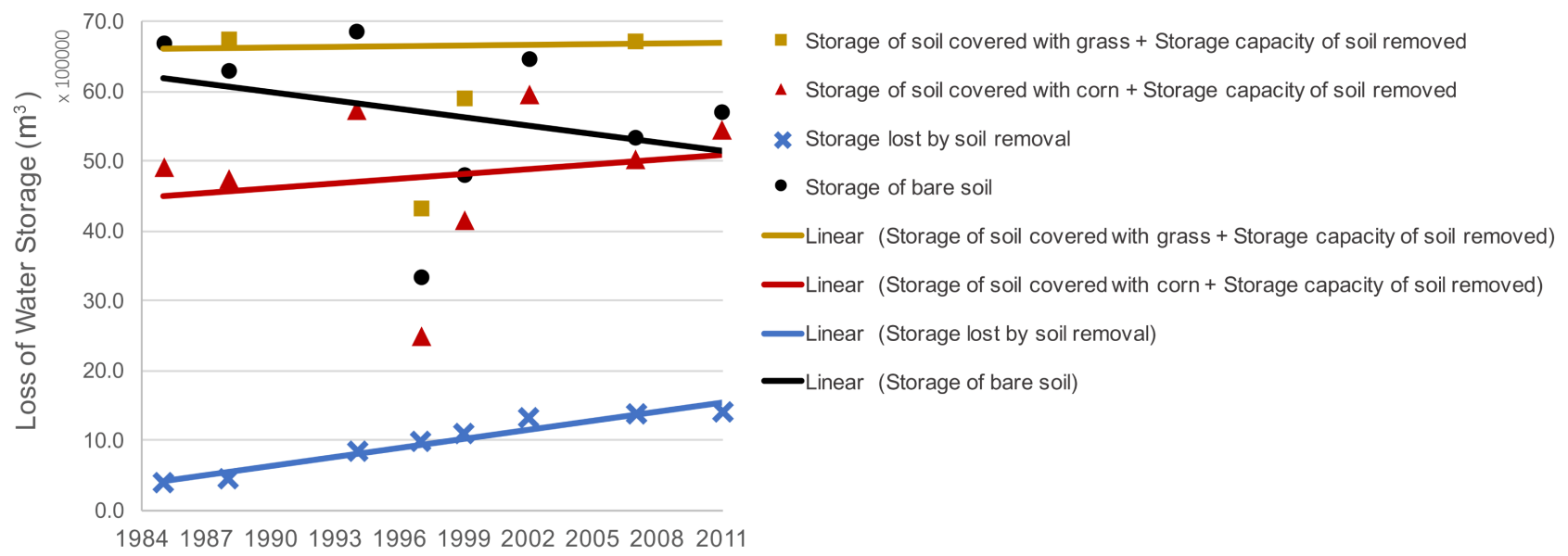

Figure 10. Change in water storage $(S)$ in Pepin Creek watershed, under different vegetative cover and bare soil scenarios. (Note: Linear trend line shows general direction of trend; not statistically significant). 
time by the Pepin Creek Watershed is almost equal to the water storage of the aggregate removed. In other words, aggregate extraction is the primary cause of the change of the water balance in the Pepin Creek watershed.

Comparing the balance of the compensation value of vegetation (whether grass or corn) has a positive trend. There is a suggestion that sweet corn is a better crop for retaining water and mitigating the negative impact of aggregate extraction on the water balance. However, sweet corn is harvested annually and the water contained in the corn is removed from the water cycle from the study area. That is, the positive trend of the red line would decrease and suggest less loss of water storage over time.

The water balance of the Pepin Creek Watershed is altered and the water storage $(S)$ is gradually decreasing. Since water storage of the removed material is a significant part of that loss, this suggests that aggregate extraction has a marked negative effect on the water balance within the watershed.

\section{Discussion}

Pepin Creek is a transboundary watershed, with a relatively mild climate that experiences little snowfall during winter, and is dependent on rainfall as the dominant form of precipitation. The watershed is rural and effects of urbanization on the hydrological cycle are relatively minor. In response to the needs for urban construction materials outside the Pepin Creek Watershed, aggregate removal has been underway for over 50 years and is expected to continue. The effects of this activity on the water storage within the area have been largely unknown.

Regulations provided by the Soil Removal and Deposit Bylaw of the City of Abbotsford [27], include detailed information about extraction activity, including types of soil, estimated depth of topsoil, estimated volume of soil removed and detailed groundwater surveys. Topsoil is stockpiled for replacement on excavated areas to be used for rehabilitation after active mining. Rehabilitation is required after the extraction activity ends. In the Pepin Creek watershed, of the 421 ha cumulative extracted area between 1984 and 2011, approximately 110 ha, or $26 \%$ of the mine site areas have undergone rehabilitation. This equates to approximately $6.7 \%$ of the Canadian portion of the watershed. There is currently no reliable information on the types or amounts of material used in rehabilitation of these aggregate extraction sites, save for the topsoil reserved and returned to the land. This amount of material is likely small in comparison to the total extracted volume of aggregate. Replanting surface vegetation and returning the site to viable agricultural production are the ultimate goals of the rehabilitation of these sites, not restoring the hydrological characteristics of the landscape. Rehabilitating these sites may result in a net increase in surface ET, but not in the water storage component.

\section{Potential Impacts}

The City of Abbotsford regulates extraction activities within the region [14]-[20]. 
The depth of aggregate extraction is limited to within 15 - 18 meters from the surface, depending on specific circumstances, in order to reduce negative influence on groundwater. This study shows that by 2011 , about $25 \%$ of the area within Pepin Creek watershed has been under aggregate extraction, and the water storage has decreased by $10 \%-20 \%$. The loss of the water storage will likely affect the contribution of the lost stored water to groundwater and surface water supplies in the watershed. A decrease in discharge during dry the season, may result in higher water temperatures, and lower volumes for other purposes in Pepin Creek. Although there is some evidence that climate change, notably temperature, may have an effect on discharge, its effects and that of changing vegetative cover have a lower impact on the water balance than the removal of the materials by aggregate mining. However, as there was no information available on groundwater dynamics in the study area and it is possible that the groundwater aquifer boundary is not congruous with the surficial boundary of the watershed, the effects and contribution of groundwater to the Pepin Creek discharge needs further evaluation.

A significant remaining question is concerns of a potential negative impact of lower discharge to Pepin Creek and the potential negative effects on cold water fish in the Creek [28], as the increased water temperature can change the metabolic rates and biological activity of fish [29]. In addition, as it is well accepted that since warmer waters contain less dissolved oxygen, most aquatic species, including some aquatic plants, experience increased respiration rates as water temperature increases, which denatures cellular enzymes leading to an irreversible reduction of biological activity of fish, if there is an oxygen deficiency [30].

\section{Conclusions}

There have been changes in the overall water balance in Pepin Creek during the time frame of this study. The analysis suggests that climate change is not the main influence on the discharge of the Pepin Creek system over the 26 years of analysis. Total precipitation, evapotranspiration and discharge, although they exhibit minor trends, are neither synchronous nor statistically significant. This may, in part, be the result of the large variation in data from year to year and the relatively short time frame of analysis. However, the yearly trend patterns for precipitation and discharge are synchronous. The removal of aggregate has resulted in a loss of surface vegetative cover of about $20 \%$ and a loss of $10 \%$ water storage, and although the effects of climate change cannot be excluded; the loss of water storage as a result of aggregate extraction appears to be the major factor in affecting the water balance in the Pepin Creek watershed. Limitations of the analysis that require additional study include an analysis of groundwater information and its contribution to the hydrological dynamics of the watershed; the decreasing volumes of discharge and to what extent these dynamics might be influenced and impacted by groundwater from adjacent watersheds. The assumption that the surficial geographical boundaries reflect the groundwater aquifer 
boundary needs further attention.

Current environmental assessments provided by extraction companies usually focus on avoiding negative impact on the environment over a short time frame, such as controlling deleterious materials entering water bodies and the disruption of groundwater systems [31]. This study suggests that regulators should conduct assessments of the impact of aggregate extraction over the length of excavation time and identify the accumulated impact on the environment, including water quantity, water quality and habitat of wildlife on a regular schedule. The indicators being monitored by Climate Canada and Water Survey Canada [11] [12], including water discharge, minimum, mean and maximum precipitation (rainfall and snowfall) and temperature, need to be continued and evaluated on a more frequent basis in an attempt to identify trends. To assess more completely the environmental and ecological effects of aggregate mining within the watershed, it is recommended that data on water temperature, water quality and dissolved oxygen, as well as groundwater dynamics be initiated.

\section{References}

[1] BC Ministry of Energy and Mines (2001) Managing Aggregate, Cornerstone of the Economy. Report of the Aggregate Advisory Panel, March 2001. Victoria, Canada. http://www.empr.gov.bc.ca/Mining/Geoscience/SurficialGeology/AggregateProject/ Review/Documents/FullReport.pdf

[2] Fraser Valley Regional District (FVRD) (2009) Fraser Valley Regional District Aggregate Pilot Project, Recommendations Report.

http://www.abbotsfordtoday.ca/wp-content/uploads/2010/10/Item-10-03-2-APP-Re commendations1.pdf

[3] Winfield, M. and Taylor, A. (2005) Rebalancing the Load: The Need for an Aggregates Conservation Strategy for Ontario. Pembina Institute for Appropriate Development. http://www.pembina.org/reports/Aggregatesfinal-web2.pdf

[4] Green, J.A., Pavlish, J.A., Merritt, R.G. and Leete, J.L. (2005) Hydraulic Impacts of Quarries and Gravel Pits. Minnesota Department of Natural Resources, Division of Waters.

http://files.dnr.state.mn.us/publications/waters/hdraulic-impacts-of-quarries.pdf

[5] Castrilli, J. (2005) Application to the Lieutenant Governor in Council regarding Dufferin Aggregates application to expand their Milton Quarry. Prepared for Coalition on the Niagara Escarpment (CONE) and Protect Our Water and Environmental Resources (POWER). http://www.torontoenvironment.org/gravel/impacts

[6] iMapBC (2013) DataBC, Province of British Columbia. http://maps.gov.bc.ca/ess/sv/imapbc/

[7] Armstrong, J.E. and Hicock, S.R. (1980) Surficial Geology, New Westminster, West of Sixth Meridian, British Columbia. Geological Survey Can. “A” Series Map.1484A, 1 Sheet.

[8] Luttmerding, H.A. (1981) Soils of the Langley-Vancouver Map Area. RAB Bulletin 18, Ministry of Environment, Map 6.

[9] UBC Geography Information Centre (2016) Department of Geography, The University of British Columbia, Canada. http://gic.geog.ubc.ca

[10] Google Earth (2016) Map Images Exported, Years 2004-2016. Google Earth Pro, 
v.7.1.5.

[11] Water Survey Canada (2016) Historical Hydrometric Data Pepin Creek. https://wateroffice.ec.gc.ca/mainmenu/historical_data_index_e.html

[12] Climate Canada (2016) Historical Climate Data for Abbotsford Airport. http://climate.weather.gc.ca/climate_data/hourly_data_e.html?hlyRange=1953-01-0 1\%7C2012-06-21\&dlyRange $=1944-10-01 \% 7 C 2012-06-20 \&$ mlyRange $=1944-01-01 \%$ 7C2012-06-01\&StationID=702\&Prov=BC\&urlExtension=_e.html\&searchType $=$ stn Prov\&optLimit=yearRange \&StartYear $=1840 \&$ EndYear $=2016 \&$ selRowPerPage $=25 \&$ Line $=10 \&$ Month $=6 \&$ Day $=21 \&$ lstProvince $=$ BC\&timeframe $=1 \&$ Year $=2012$

[13] ESRI (2016) ArcGIS Desktop: Release 10. Environmental Systems Research Institute, Redlands.

[14] City of Abbotsford Council Report (2001) Application for Soil Removal at 1563 Ross Road. https://abbotsford.civicweb.net/document/4591

[15] City of Abbotsford Council Report (2001) Application for Soil Removal at 28473 Huntingdon Road. https://abbotsford.civicweb.net/document/4610

[16] City of Abbotsford Council Report (2005) Application for Soil Removal at 2676 Ross Road. https://abbotsford.civicweb.net/document/7458

[17] City of Abbotsford Council Report (2006) Resubmission of Soil Removal Application for 2676 Ross Road. L.P. Management Corporation. https://abbotsford.civicweb.net/document/13875

[18] City of Abbotsford Council Report (2007) Application for Soil Removal at 29969 Simpson Road. https://abbotsford.civicweb.net/document/9068

[19] City of Abbotsford Council Report (2007) Application for Soil Removal at Lot 1 Plan 23517 by Little Rock Quarries Ltd. https://abbotsford.civicweb.net/document/8643

[20] City of Abbotsford Council Report (2008) Draft South West Abbotsford Soil Removal Study Presentation.

https://abbotsford.civicweb.net/filepro/document/9311/ENG\%2001-2008.doc?handl $\mathrm{e}=2 \mathrm{DA} 5 \mathrm{ABC} 290 \mathrm{~F} 14 \mathrm{~F} 3 \mathrm{E} 8 \mathrm{~B} 69 \mathrm{E} 850 \mathrm{EEF} 150 \mathrm{BD}$

[21] Van der Gulik, T., Neilson, D., Fretwell, R. and Tam, S. (2015) Agricultural Water Demand Model: Fraser Valley Regional District. B.C. Ministry of Agriculture. http://www.llbc.leg.bc.ca/public/pubdocs/bcdocs2016/599317/500300-14_agric_wat er_demand_model_fvrd_report_feb13_2015.pdf

[22] Kristensen, K.J. and Jensen, S.E. (1975) A Model for Estimating Actual Evapotranspiration from Potential Evapotranspiration. Hydrology Research, 6, 170-188.

[23] Spittlehouse, D.L. (1989) Estimating Evapotranspiration from Land Surfaces in British Columbia. Proceedings of a Workshop, Vancouver, August 1987, No. 177, 245-256.

[24] Winkler, R.D., Moore, R.D., Redding, T.E., Spittlehouse, D.L., Smerdon, B.D. and Carlyle-Moses, D.E. (2010) The Effects of Forest Disturbance on Hydrologic Processes and Watershed Response. In: Pike, R.G., Redding, T.E., Moore, R.D., Winkler, R.D. and Bladon, K.D., Eds., Compendium of Forest Hydrology and Geomorphology in British Columbia, BC Ministry of Forests and Range, Land Management Handbook 66, 179-212.

[25] Matan, E. (2013) Growth Morphology of Corn. Presentation for USAID Small Business Expansion Project.

http://www.slideshare.net/USAID-SBEP/corn-growth-morphology

[26] Farmwest (2016) Evapotranspiration-Abbotsford Airport. 
http://www.farmwest.com/climate/et

[27] City of Abbotsford (2003) City of Abbotsford Consolidated Soil Removal and Deposit Bylaw. https://abbotsford.civicweb.net/document/5669

[28] Lessard, J.L. and Hayes, D.B. (2003) Effects of Elevated Water Temperature on Fish and Macroinvertebrate Communities below Small Dams. River Research and Applications, 19, 721-732. https://doi.org/10.1002/rra.713

[29] Wetzel, R.G. (2001) Limnology: Lake and River Ecosystems. 3rd Edition, Academic Press, San Diego.

[30] Pearson Education, Inc. (2016) In Measuring Temperature and Metabolic Rate. http://www.phschool.com/science/biology_place/labbench/lab10/temprate.html

[31] Thompson, A. and Howarth, C. (2007) Reducing the Effect of Aggregate Quarrying on the Water Environment. 36.

http://www.sustainableaggregates.com/docs/revs/t1b_water.pdf

\section{Scientific Research Publishing}

Submit or recommend next manuscript to SCIRP and we will provide best service for you:

Accepting pre-submission inquiries through Email, Facebook, LinkedIn, Twitter, etc. A wide selection of journals (inclusive of 9 subjects, more than 200 journals)

Providing 24-hour high-quality service

User-friendly online submission system

Fair and swift peer-review system

Efficient typesetting and proofreading procedure

Display of the result of downloads and visits, as well as the number of cited articles

Maximum dissemination of your research work

Submit your manuscript at: http://papersubmission.scirp.org/

Or contact nr@scirp.org 